\title{
Efektivitas Limbah Cengkih dalam Menekan Perkembangan In Vitro Sclerotium rolfsii, Jamur Penyebab Damping Off Kacang Tanah
}

\section{The Effectiveness of Clove Waste in Suppressing In Vitro Development of Sclerotium rolfsii Fungus That Causes Damping Off in Peanuts}

\section{Handry R.D. Amanupunyo1,*, Nace E. Tahitu², Gratiana N.C. Tuhumury ${ }^{1}$}

\author{
${ }^{1}$ Jurusan Budidaya Pertanian, Fakultas Pertanian, Universitas Pattimura, Jl. Ir. M. Putuhena, Kampus Poka, Ambon \\ 97233, Indonesia \\ ${ }^{2}$ Program Studi Agroteknologi, Jurusan Budidaya Pertanian, Fakultas Pertanian, Universitas Pattimura, Jl. Ir. M. \\ Putuhena, Kampus Poka, Ambon 97233, Indonesia \\ *E-mail Penulis Korespondensi: hamanupunyo@gmail.com
}

\begin{abstract}
Various problems have caused the decline in peanut production, among others the low resistance of peanut plants to various diseases. One of the obstacles in peanut production is the attack of plant diseases, such as the fungus Sclerotium rolfsii Sacc. The use of plant-based insecticides can be an alternative to disease control in peanuts. This study aimed to obtain the appropriate and effective dose of clove leaves and flower stalks in suppressing the in vitro growth of the fungus S. rolfsii Sacc causing damping off in peanuts, and to test the effectiveness of clove leaves and flower stalks on the formation of sklerotia of the fungus. This study used 'tuni' clove powder from Waai Village, Salahutu District. This experimental study employed a completely randomized design (CRD) with 8 treatments and 3 replications. The results showed that the growth of the fungus $S$. rolfsii Sacc. was inhibited by clove flower stalk powder at a dose of $1.5 \mathrm{~g}$ per $100 \mathrm{~mL}$ of PDA, which was indicated by the number of sklerotia formed of $13.67 \%$ and propagule weight of $0.12 \mathrm{~g}$, followed by a dose of clove leaf powder of $1.5 \mathrm{~g}$ per $100 \mathrm{~mL} P D A$, with amount of sklerotia formed of $27.33 \%$ and propagule weight of $0.17 \mathrm{~g}$. These results were statistically shown on the parameters: colony diameter, Sklerotia formation time, number of Sklerotia, and weight of propagules.
\end{abstract}

Keywords: Clove powder, dosage, in vitro, Sclerotium rolfsii Sacc.

\section{ABSTRAK}

Berbagai masalah telah menyebabkan turunnya produksi kacang tanah, diantaranya masih rendahnya ketahanan tanaman kacang tanah terhadap berbagai penyakit. Salah satu kendala dalam produksi kacang tanah adalah serangan penyakit tanaman, seperti jamur Sclerotium rolfsii Sacc. Penggunaan insektisida nabati dapat menjadi alternatif pengendalian penyakit pada kacang tanah. Penelitian ini bertujuan untuk memperoleh dosis daun dan tangkai bunga cengkih yang tepat dan efektif dalam menekan pertumbuhan jamur $S$. rolfsii Sacc penyebab damping off pada kacang tanah secara in vitro, serta menguji efektifitas daun dan tangkai bunga cengkih terhadap pembentukan sklerotia jamur. Penelitian ini menggunakan bubuk cengkih tuni, dari Desa Waai, Kecamatan Salahutu. Penelitian eksperimental ini menggunakan Rancangan Acak Lengkap (RAL) dengan 8 perlakuan dan 3 ulangan. Hasil penelitian menunjukkan bahwa pertumbuhan jamur $S$. rolfsii Sacc. terhambat oleh bubuk tangkai bunga cengkih pada dosis $1,5 \mathrm{~g}$ per $100 \mathrm{~mL}$ PDA yang ditunjukan oleh jumlah sklerotia terbentuk $13,67 \%$ dan berat propagul $0,12 \mathrm{~g}$ dan diikuti oleh dosis bubuk daun cengkih $1,5 \mathrm{~g}$ per $100 \mathrm{~mL}$ PDA, dengan jumlah sklerotia 27,33\% dan berat propagul 0,17 g. Hasil ini secara statistik ditunjukkan pada parameter: diameter koloni, waktu terbentuk sklerotia, jumlah sklerotia, dan berat propagul.

Kata kunci: bubuk cengkih, dosis, in vitro, Sclerotium rolfsii Sacc.

\section{PENDAHULUAN}

Kacang tanah merupakan salah satu tanaman pangan yang memiliki nilai ekonomi tinggi serta mempunyai peranan penting dalam mencukupi kebutuhan bahan pangan. Kacang tanah memiliki kandungan protein $25-30 \%$, lemak 40-50\%, karbohidrat 12\% dan vitamin (Cibro, 2008). Penurunan luas panen dan produksi kacang tanah antara lain disebabkan berbagai kendala diantaranya masih rendahnya ketahanan tanaman tanaman ini terhadap penyakit. Salah satu kendalanya adalah serangan oganisme pengganggu, seperti jamur S.rolfsii Sacc. yang menyebabkan rebah semai atau damping off (Timper et al., 2001).

Kerugian hasil kacang tanah akibat serangan penyakit rebah kecambah cukup tinggi mencapai 13-59\%. Kehilangan hasil akibat serangannya dapat mencapai 30\% pada lahan-lahan yang selalu ditanami kedelai dan kacangkacangan lainnya. Jamur penyebab penyakit ini mempunyai penyebaran yang sangat luas di seluruh dunia dan 
menyerang banyak spesies tanaman pertanian khususnya sayuran (Punja, 1985; Fichtner, 2010). Tingkat serangan 5\% di lapangan sudah dapat merugikan secara ekonomi (Sumartini, 2012).

Pengendalian penyakit ini pada tanaman kacang tanah cenderung dilakukan dengan memakai pestisida . Menurut Cesniket et al., (2006), aplikasi fungisida kimia sintetis dalam mengendalikan S. rolfsii Sacc menimbulkan dampak negatif, yakni dapat menimbulkan residu pestisida pada produk pertanian, serta resistensi dan resurgensi penyakit. Pemanfaatan pestisida nabati memiliki beberapa kelebihan, antara lain bersifat ramah lingkungan, murah, mudah didapat, tidak meracuni tanaman, tidak menimbulkan resistensi penyakit, serta mengandung unsur hara yang diperlukan tanaman (Irfan, 2016; Tawa, 2016; Nurmansyah, 2016).

Cengkih sebagai salah satu tanaman perkebunan yang banyak di Maluku dapat digunakan sebagai pestisida nabati untuk pengendalian organisme pengganggu tanaman. Terkait hal tersebut maka dalam penelitian ini dicobakan pestisida nabati dari daun dan tangkai bunga cengkih dalam menekan perkembangan jamur S. rolfsii Sacc. Tujuan dari penelitian ini adalah untuk memperoleh dosis daun dan gagang cengkih yang tepat dalam menekan pertumbuhan jamur S. rolfsii Sacc, dan menguji efektivitas daun dan tangkai bunga cengkih terhadap pembentukan sklerotia (sclerotia) jamur $S$. rolfsii Sacc.

\section{BAHAN DAN METODE}

Penelitian ini dilaksanakan di Laboratorium Penyakit Tumbuhan Fakultas Pertanian, Universitas Pattimura Ambon, mulai dari bulan Februari-Agustus 2020.

Dalam penelitian ini digunakan rancangan acak lengkap (RAL) dengan 3 ulangan, dan terdapat 24 satuan percobaan. Perlakuannya adalah penambahkan bubuk cengkih dengan dosis yang berbeda ke dalam media PDA, meliputi bubuk tangkai bunga cengkih, daun cengkih dan fungisida Dithane M45 (sebagai kontrol positif) dengan dosis 0,5 g per $100 \mathrm{~mL}$ media PDA, $1 \mathrm{~g}$ per $100 \mathrm{~mL}$ media PDA dan 1,5 g per $100 \mathrm{~mL}$ media PDA. Bahan bubuk cengkih diperoleh dari dari Desa Waai, Kecamatan Salahutu. Secara keseluruhan, perlakuan-perlakuan dalam penelitian ini adalah: A0: tanpa bubuk cengkih (kontrol negatif); A: dengan bubuk tangkai bunga cengkih dosis $0.5 \mathrm{~g}$ per $100 \mathrm{~mL}$ PDA; B: dengan bubuk tangkai bunga cengkih dosis $1.0 \mathrm{~g}$ per $100 \mathrm{~mL}$ PDA; C: dengan bubuk tangkai bunga cengkih dosis $1.5 \mathrm{~g}$ per $100 \mathrm{~mL}$ PDA; D: dengan bubuk daun cengkih dosis $0.5 \mathrm{~g}$ per $100 \mathrm{~mL}$ PDA; E: dengan bubuk daun cengkih dosiss $1.0 \mathrm{~g}$ per $100 \mathrm{~mL}$ PDA; F: dengan bubuk daun cengkih dosis $1.5 \mathrm{~g}$ per $100 \mathrm{~mL}$ PDA; dan G: dengan fungisida Dithane M45 dosis anjuran (kontrol positif). Variabel yang diamati meliputi: diameter koloni jamur, waktu terbentuknya sklerotia, jumlah sklerotia yang terbentuk dan berat propagul.

Analisis data menggunakan analisis ragam, dan bila hasil pengujian menunjukkan pengaruh perlakuan yang nyata dilanjutkan dengan uji BNJ pada taraf 0,05 .

\section{Prosedur Kerja}

\section{Isolasi jamur Sclerotium rolfsii}

Isolasi dilakukan dengan mengambil bagian jaringan tanaman yang sakit, hifa, dan Sclerotium, kemudian dipotong mengunakan gunting stril dan diletakan pada tisyu, kemudian dikulturkan pada media PDA dan diinkubasi pada suhu ruangan sampai muncul pertumbuhan jamur S.rolfsii Sacc. Hasil isolasi dipindahkan ke media PDA untuk dimurnikan, dan disimpan pada biakan murni untuk selanjutnya digunakan dalam penelitian.

\section{Penyiapan bubuk cengkih}

Tangkai bunga cengkih dan daun cengkih yang telah diperoleh dari lapangan, dijemur hingga kering, disterilkan menggunakan alkohol, digerus dengan grinder dan disaring hingga halus, timbang sesuai dosis dan dimasukan dalam kertas steril, untuk selanjutnya digunakan dalam penelitian.

\section{Penanaman jamur Sclerotium rolfsii}

Bubuk cengkih sesuai perlakuan dan $10 \mathrm{~mL}$ media PDA dimasukan dalam cawan petri dan diinokulasi dengan kultur jamur $S$. rolfsii Sacc yang bergaris tengah $5 \mathrm{~mm}$ (dibuat menggunakan bor gabus) dan diinkubasi pada suhu kamar untuk dilakukan pengamatan selanjutnya.

\section{HASIL DAN PEMBAHASAN}

\section{Isolat Jamur Sclerotium rolfsi Sacc.}

Tanaman kacang tanah yang terinfeksi jamur S. rolfsii Sacc, terlihat disekitar pangkal batangnya terdapat miselium berwarna putih. Apabila diambil dan dibiakkan pada media kultur, akan tumbuh seperti jalinan benang halus menyerupai kipas pada media PDA. Jamur ini tumbuh dengan koloni menyerupai kipas, berwarna putih, dan membentuk hifa-hifa udara waktu terjadi pertumbuhan sklerotia pada media biakan 11-22 hari. 


\section{Pertumbuhan Diamter Koloni Jamur Sclerotium rolfsii Sacc.}

Pertumbuhan jamur pada perlakuan $\mathrm{C}$ arah grafiknya menurun, serta kecil peningkatan terhadap pertumbuhan miselium jamur S. rolfsii Sacc (Gambar 2). Perlakuan C berbeda nyata dengan perlakuan lainnya, perlakuan C memiliki nilai rata-rata pada hari ke-5 sebesar 5,2 cm. Pemberian bubuk tangkai bunga cengkih pada media PDA mengakibatkan pertumbuhan miselium jamur menjadi tertekan atau terhambat. Ini dikarenakan media tumbuh jamur telah teracuni oleh bubuk cengkih sehingga media tidak sesuai untuk pertumbuhan jamur. Pada bubuk tangkai bunga cengkih terdapat zatzat kimia yang dapat menekan pertumbuhan jamur. Hasil penelitian Novita, (2008) menunjukkan bahwa minyak cengkih memiliki kemampuan melarutkan lemak pada dinding sel jamur, maka terjadi penekanan pertumbuhan dan perkembangan jamur patogen. Kandungan minyak atsiri pada tangkai bunga cengkih lebih tinggi dibandingkan dengan daun cengkih, Menurut Tawa et al. (2017), bagian tangkai bunga cengkih memiliki kandungan minyak atsri 21,3\%, dan daun cengkih $6 \%$.

Perlakuan C jika dibandingkan dengan kontrol negatif berbeda nyata berdasarkan uji BNJ taraf 5\% karena perlakuan C lebih baik dalam menekan pertumbuhan diameter koloni jamur S.rolfsii pada media PDA (Gambar 2). Jika perlakuan $\mathrm{C}$ dibandingkan dengan kontrol postif, yaitu penambahan Dithane M45, berdasarkan hasil uji BNJ taraf 5\% berbeda nyata. Karena kontrol positif dapat menghentikan pertumbuhan jamur S.rolfsii Sacc pada media PDA, pada perlakuan $C$ hanya menekan pertumbuhan jamur S.rolfsii Sacc pada media PDA. Bila dibandingkan dengan perlakuan lainnya (A, B, D, E, dan F) perlakuan $\mathrm{C}$ berbeda nyata, artinya bubuk tangkai cengkih lebih baik dalam menekan diameter koloni jamur pada media PDA (Gambar 2).

\section{Waktu Terbentuknya Sklerotia}

Perlakuan C memiliki waktu terbentuk sklerotia berbeda nyata dengan perlakuan lainnya berdasarkan uji BNJ taraf 0,05, karena proses pembentukan Sklerotia pada media PDA berumur 13-16 hari, hal ini disebabkan karena pemberian bubuk cengkih pada media PDA menyebabkan media teracuni, sehingga cadangan makanan tidak tersediah untuk pertumbuhan Gambar 4. Pada Perlakuan (C), saat jamur stress atau tertekan jamur tidak mampu berproses untuk membentuk Sklerotia lebih awal, karena hifa pada media beracun mengalami perubahan atau abnormal sehingga hifa tidak mampu membentuk Sklerotia dengan cepat dan pertumbuhan miselium pada media PDA lebih tipis, serta hifa udara tidak banyak pada media PDA. Menurut hasil penelitian Nurmansyah (2016), komponen minyak atsiri mampu menembus dinding sel jamur dan bakteri maka terganggunya proses metabolisme dan Menurut Novita (2008), komponen minyak atsiri mampu melarutkan lemak pada dinding sel, sehingga dinding sel menjadi tidak selektif.

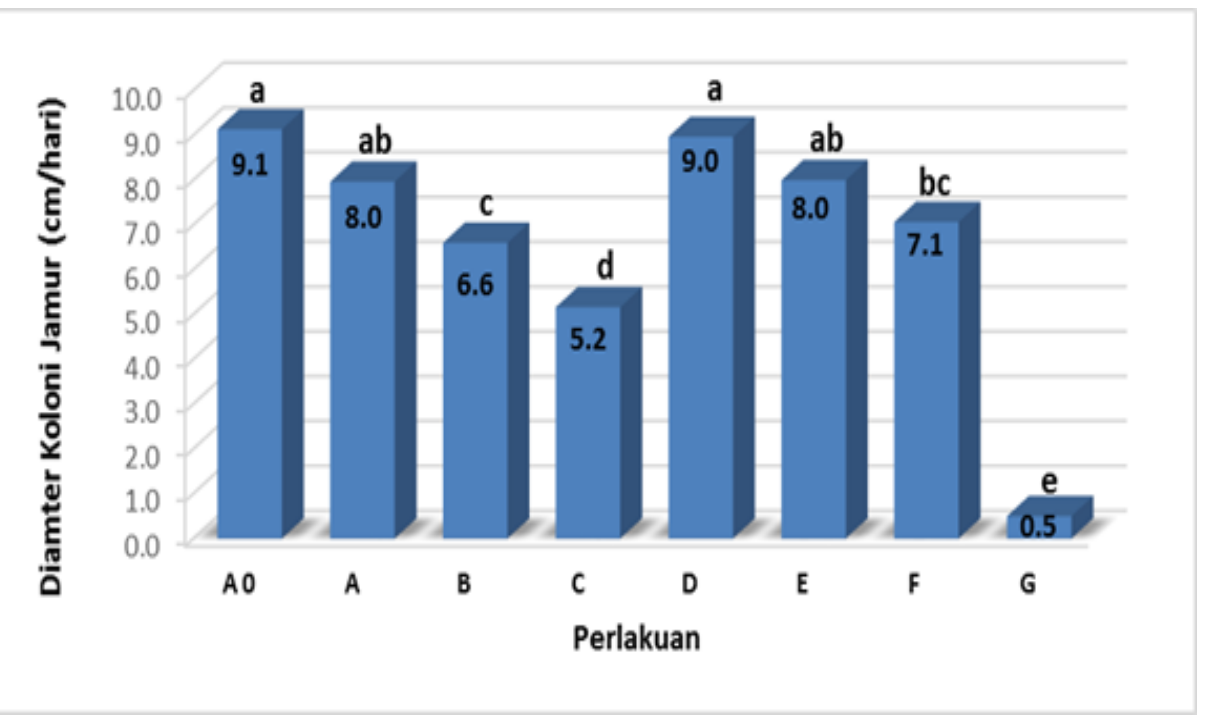

Keterangan: A0: tanpa bubuk cengkih (kontrol negatif); A: dengan bubuk tangkai bunga cengkih dosis 0.5 g per $100 \mathrm{~mL}$ PDA; B: dengan bubuk tangkai bunga cengkih dosis 1.0 g per $100 \mathrm{~mL}$ PDA; $\mathrm{C}$ : dengan bubuk tangkai bunga cengkih dosis $1.5 \mathrm{~g}$ per $100 \mathrm{~mL}$ PDA; D: dengan bubuk daun cengkih dosis $0.5 \mathrm{~g}$ per $100 \mathrm{~mL}$ PDA; E: dengan bubuk daun cengkih dosiss $1.0 \mathrm{~g}$ per $100 \mathrm{~mL}$ PDA; F: dengan bubuk daun cengkih dosis $1.5 \mathrm{~g}$ per $100 \mathrm{~mL}$ PDA; G: dengan fungisida Dithane M45 dosis anjuran (kontrol positif)

Gambar 2. Grafik rata-rata diameter koloni jamur S. rolfsii Sacc. pada hari ke-5. 


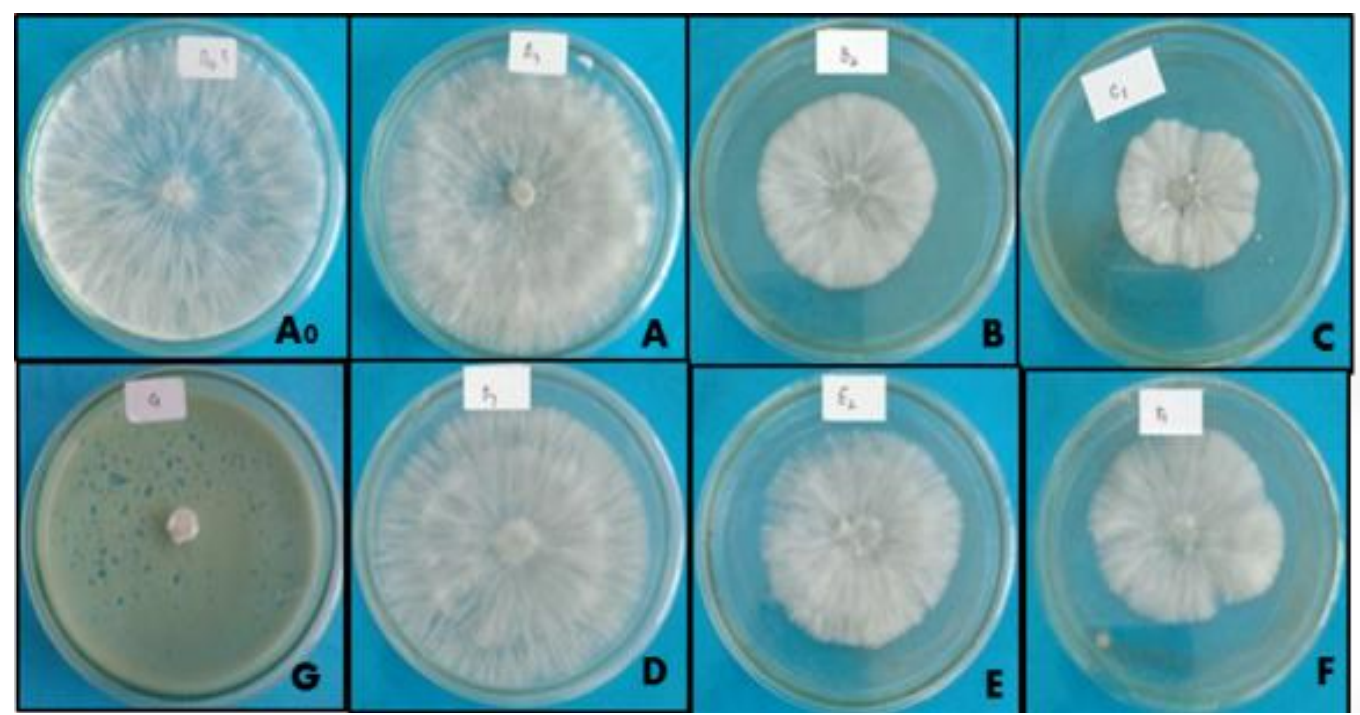

Keterangan: A0: tanpa bubuk cengkih (kontrol negatif); A: dengan bubuk tangkai bunga cengkih dosis $0.5 \mathrm{~g}$ per $100 \mathrm{~mL}$ PDA; B: dengan bubuk tangkai bunga cengkih dosis $1.0 \mathrm{~g}$ per $100 \mathrm{~mL}$ PDA; C: dengan bubuk tangkai bunga cengkih dosis $1.5 \mathrm{~g}$ per $100 \mathrm{~mL}$ PDA; D: dengan bubuk daun cengkih dosis $0.5 \mathrm{~g}$ per $100 \mathrm{~mL}$ PDA; E: dengan bubuk daun cengkih dosiss $1.0 \mathrm{~g}$ per $100 \mathrm{~mL}$ PDA; F: dengan bubuk daun cengkih dosis $1.5 \mathrm{~g}$ per $100 \mathrm{~mL}$ PDA; G: dengan fungisida Dithane M45 dosis anjuran (kontrol positif)

Gambar 3. Pertumbuhan diameter koloni jamur S. rolfsii Sacc.

Jika dibandingkan antara perlakuan $\mathrm{C}$ dengan kontol negatif maka didapatkan bahwa perlakuan $\mathrm{C}$ lebih baik dalam menekan pembentukan sklerotia serta menganggu pembentukan sistem hifa jamur dibandingkan dengan kontrol negatif, karena pada kontrol negatif terbentuknya sklerotia terjadi pada umur 21-22 hari, yakni pembentukan sklerotia lebih lambat. Hasil penelitian Sumartini (2012) menunjukkan bahwa sklerotia baru terbentuk setelah 8-11 hari. Saat proses penelitian suhu ruangan adalah $25^{\circ} \mathrm{C}$, yang adalah suhu optimal bagi pertumbuhan miselium jamur, sehingga kondisi masih cocok untuk jamur S.rolfsii Sacc tumbuh. Menurut hasil penelitian Amanupunjo (1997) dan Semangun (2004), suhu optimal yang dibutuhkan untuk pertumbuhan $S$. rolfsii Sacc adalah $25-35^{\circ} \mathrm{C}$, dengan suhu minimum $8^{\circ} \mathrm{C}$ dan suhu maksimum $32^{\circ} \mathrm{C}$. Hasil penelitian Fitchtner (2010), mendapatkan bahwa sklerotia akan berkecambah pada kisaran kelembaban 25-30\%.

Jika perlakuan $\mathrm{C}$ dibandingkan dengan kontrol postif maka, kontrol positif lebih menekan pertumbuhan jamur daripada perlakuan $\mathrm{C}$ karena kontrol postif menghentingkan pertumbuhan jamur sehingga jamur tidak dapat bertumbuh dan membentuk sklerotia pada media PDA (Gambar 4).

\section{Jumlah Sklerotia yang Terbentuk}

Pada perlakuan C memiliki jumlah sklerotia lebih sedikit dibandingkan dengan perlakuan yang lain (Gambar 5). Pada perlakuan $\mathrm{C}$ memiliki dosis bubuk cengkih lebih tinggi dibandingkan dengan dosis lainnya, pada perlakuan $\mathrm{C}$ terbentuk hifa abnormal. Menurut hasil penelitian Novita (2008), kemampuan eugenol yang terkandung pada bubuk cengkih mampu merusak sel cendawan. Menurut Ueda et al. (1982), eugenol memiliki aktivitas antibiotik melawan cendawan dan bakteri dan menurut Giordani et al. (2008), eugenol memiliki aktivitas fungistatik.

Jika dibandingkan antara perlakuan $\mathrm{C}$ dengan kontrol negatif diperoleh bahwa perlakuan $\mathrm{C}$ lebih baik. Hal ini karena bubuk cengkih menyebabkan hifa menjadi abnormal sehingga pembentukan sklerotia terhambat, sedangkan pada kontrol negatif pembentukan sklerotia sedikit karena suhu ruang $25^{\circ} \mathrm{C}$. Menurut Fitchtner (2010), sklerotia akan berkecambah pada kisaran kelembaban 25-30\%. Menurut Tawa et al. (2017), sklerotia merupakan struktur istirahat dari jamur S. rolfsii Sacc. Jika dibandingkan dengan kontrol postif maka perlakuan C berbeda nyata karena pada kontrol postif tidak terdapat pertumbuhan jamur pada media PDA (Gambar 5).

Pada penelitian ini ditemui pertumbuhan sklerotia pada tepi-tepi cawan Petri atau di ujung-ujung hifa, karena jamur telah menjauh dari sumber makanan dalam media PDA (Gambar 6). Menurut hasil penelitian Solichah (2010), S. rolfsii Sacc merupakan parasit tular tanah yang cukup berbahaya bagi tanaman karena dapat bertahan hidup sangat lama dalam bentuk sklerotia. Sklerotia memiliki bentuk bulat serta memiliki struktur yang sangat keras. Menurut hasil penelitian Lolong (2016), sklerotia mempunyai kulit tebal dan keras sehingga tahan terhadap keadaan lingkungan yang tidak menguntungkan. Triastuti (2012) menyatakan bahwa sklerotia merupakan kumpulan miselium memadat berbentuk butiran keras berwarna putih sampai kecoklatan. Setelah diamati secara mikroskopik di sekitaran sklerotia terdapat gelembung-gelembung kecil yang menempel, berwarna putih serta kelihatan berminyak. 


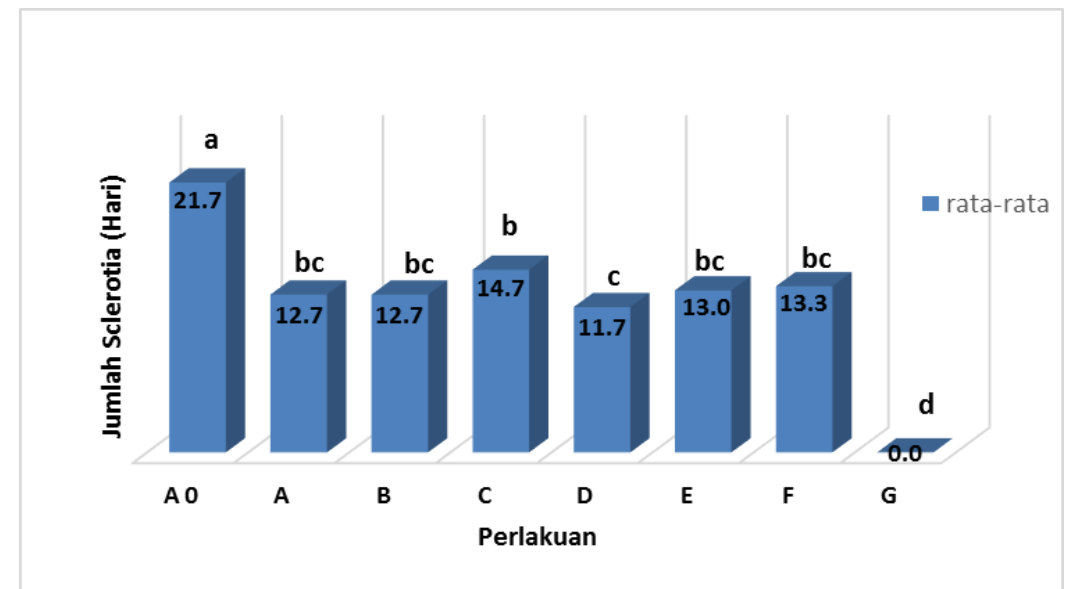

Keterangan: A0: tanpa bubuk cengkih (kontrol negatif); A: dengan bubuk tangkai bunga cengkih dosis $0.5 \mathrm{~g}$ per $100 \mathrm{~mL}$ PDA; B: dengan bubuk tangkai bunga cengkih dosis $1.0 \mathrm{~g}$ per $100 \mathrm{~mL}$ PDA; C: dengan bubuk tangkai bunga cengkih dosis $1.5 \mathrm{~g}$ per $100 \mathrm{~mL}$ PDA; D: dengan bubuk daun cengkih dosis $0.5 \mathrm{~g}$ per $100 \mathrm{~mL}$ PDA; E: dengan bubuk daun cengkih dosiss $1.0 \mathrm{~g}$ per $100 \mathrm{~mL}$ PDA; F: dengan bubuk daun cengkih dosis $1.5 \mathrm{~g}$ per $100 \mathrm{~mL}$ PDA; G: dengan fungisida Dithane M45 dosis anjuran (kontrol positif)

Gambar 4. Grafik waktu terbentuknya sklerotia pada medium PDA

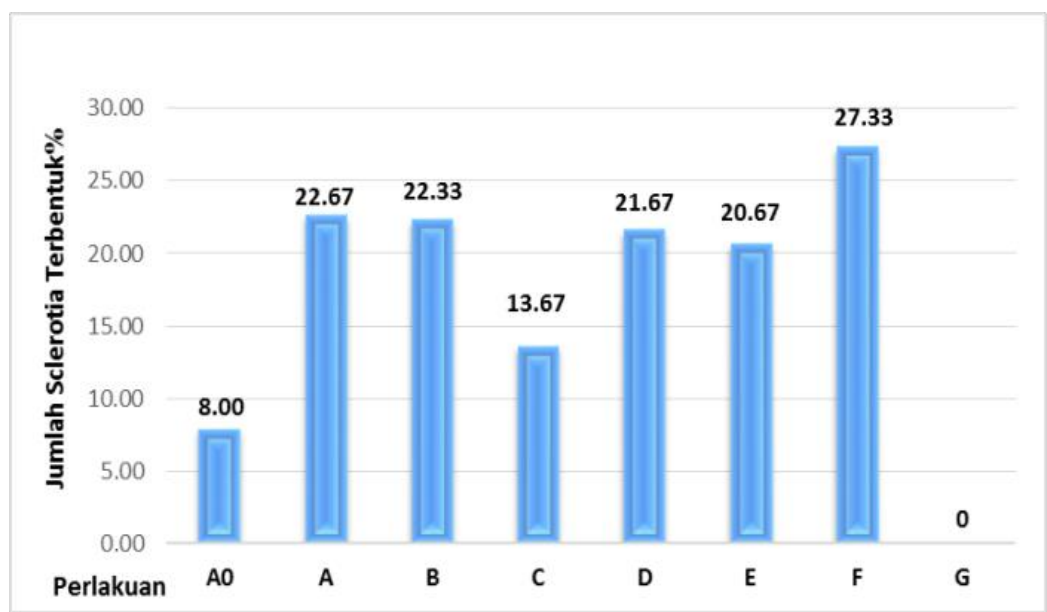

Keterangan: A0: tanpa bubuk cengkih (kontrol negatif); A: dengan bubuk tangkai bunga cengkih dosis $0.5 \mathrm{~g}$ per $100 \mathrm{~mL}$ PDA; B: dengan bubuk tangkai bunga cengkih dosis $1.0 \mathrm{~g}$ per $100 \mathrm{~mL}$ PDA; $\mathrm{C}$ : dengan bubuk tangkai bunga cengkih dosis $1.5 \mathrm{~g}$ per $100 \mathrm{~mL}$ PDA; D: dengan bubuk daun cengkih dosis $0.5 \mathrm{~g}$ per $100 \mathrm{~mL}$ PDA; E: dengan bubuk daun cengkih dosiss $1.0 \mathrm{~g}$ per $100 \mathrm{~mL}$ PDA; F: dengan bubuk daun cengkih dosis $1.5 \mathrm{~g}$ per $100 \mathrm{~mL}$ PDA; G: dengan fungisida Dithane M45 dosis anjuran (kontrol positif)

Gambar 5. Grafik rata-rata jumlah sklerotia terbentuk pada umur 24 hari.

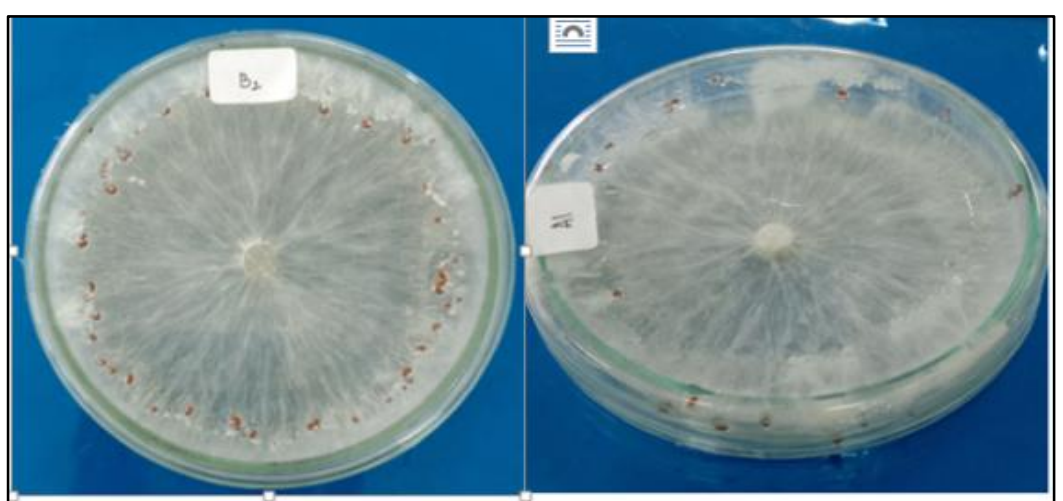

Gambar 6. Pertumbuhan sklerotia pada ujung hifa atau tepi cawan Petri pada media PDA 


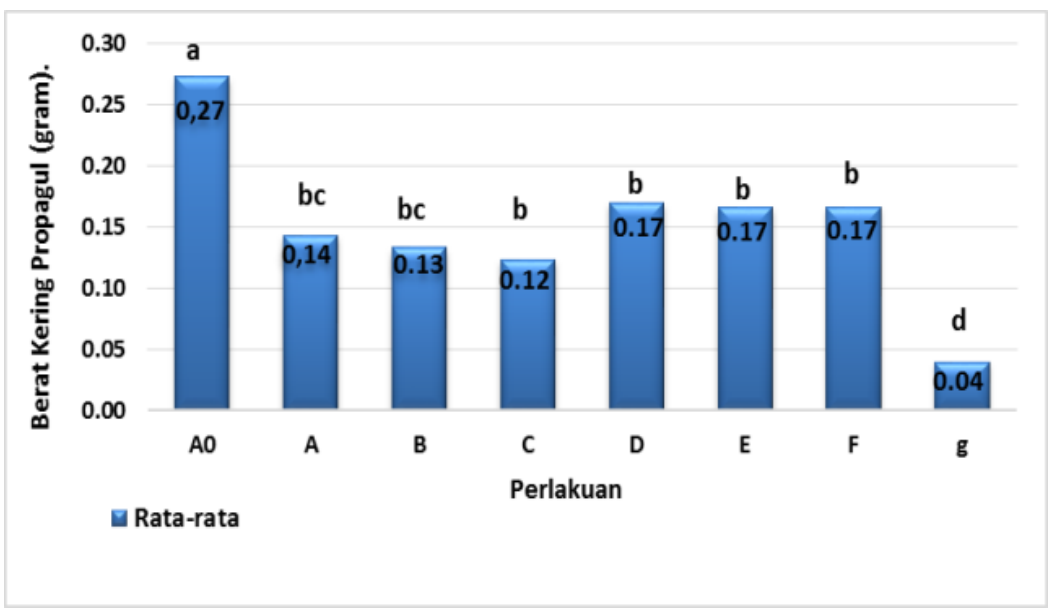

Keterangan: A0: tanpa bubuk cengkih (kontrol negatif); A: dengan bubuk tangkai bunga cengkih dosis $0.5 \mathrm{~g}$ per $100 \mathrm{~mL}$ PDA; B: dengan bubuk tangkai bunga cengkih dosis $1.0 \mathrm{~g}$ per $100 \mathrm{~mL}$ PDA; C: dengan bubuk tangkai bunga cengkih dosis $1.5 \mathrm{~g}$ per 100 mL PDA; D: dengan bubuk daun cengkih dosis $0.5 \mathrm{~g}$ per $100 \mathrm{~mL}$ PDA; E: dengan bubuk daun cengkih dosiss 1.0 g per $100 \mathrm{~mL}$ PDA; F: dengan bubuk daun cengkih dosis 1.5 g per $100 \mathrm{~mL}$ PDA; G: dengan fungisida Dithane M45 dosis anjuran (kontrol positif)

Gambar 7. Rata-rata berat kering propagul pada berbagai perlakuan

\section{Berat Kering Propagul}

Pada hasil penelitian ini didapatkan bahwa berat kering propagul pada masing-masin g perlakuan berbeda. Perlakuan C memiliki berat propagul $0,12 \mathrm{~g}$ berbeda nyata dengan perlakuan lain. Ini disebabkan karena hifa abnormal yang terbentuk membuat masa/berat pada perlakuan $\mathrm{C}$ mengalami penurunan. Jika dibandingkan dengan kontrol positif (G) diperoleh berat propagul $0.04 \mathrm{~g}$, yang berbeda nyata dengan perlakuan lainnya, karena pada $\mathrm{G}$ tidak terjadi pertumbuhan jamur pada media PDA. Jika perlakuan C dibandingkan perlakuan A dan B maka tidak berbeda nyata, karena berat dari kedua perlakuan ini tidak terlalu berbeda jauh. Berat propagul pada perlakuan ini lebih ringan karena pemberian bubuk cengkih, dimana bubuk cengkih mengandung minyak atsiri dan dalam minyak atsiri terkandung eugenol yang mampu merusak sel dari jamur. Semakin tinggi dosis yang diberikan maka semakin tinggi eugenol yang terkandung dalam bubuk cengkih (Gambar 7).

Menurut hasil penelitian Tawa et al. (2017), senyawa eugenol yang terkandung dalam daun dan gagang cengkih mampu merusak sel jamur patogen. Dan jika dibandingkan dengan perlakuan Perlakuan D, E, F, tidak berbeda nyata hal ini disebabkan karena pemberian bubuk cengkih yang berbeda pada tiap perlakuan membuat masing-masin $g$ perlakuan memiliki berat yang beragam. Pada ketiga perlakuan diberikan bubuk daun cengkih, berbeda dengan pemberian bubuk tangkai bunga cengkih, hal ini disebabkan karena minyak atsiri dari tangkai bunga cengkih lebih tinggi dibandingkan dengan pemberian minyak atsiri pada daun cengkih, maka kandungan unsur-unsur kimia juga berbeda. Menurut hasil penelitian Tawa et al., (2017), bagian gagang cengkih memiliki kandungan minyak atsri 21,3\%, daun cengkih memiliki kandungan minyak atsiri $6 \%$.

\section{KESIMPULAN}

Berdasarkan hasil penelitian ini maka dapat disimpulkan:

1. Perlakuan $\mathrm{C}$ (dosis $1,5 \mathrm{~g}$ per $100 \mathrm{~mL}$ PDA tangkai bunga cengkih) dan perlakuan $\mathrm{F}$ (dosis $1,5 \mathrm{~g}$ per $100 \mathrm{~mL}$ PDA daun cengkih), mampu menekan pertumbuhan jamur $S$. rolfsii Sacc secara in vitro.

2. Jumlah sklerotia pada perlakuan $\mathrm{C}$ (dosis $1,5 \mathrm{~g}$ per $100 \mathrm{~mL}$ PDA tangkai bunga cengkih) adalah 13,67 , dan berat propagul 0,12 g; jumlah sklerotia pada perlakuan F (dosis 1,5 g per $100 \mathrm{~mL}$ PDA daun cengkih), adalah 27,33, dan berat propagul $0,17 \mathrm{~g}$.

\section{DAFTAR PUSTAKA}

Amanupunyo, H.R.D. 1997. Pengaruh Bubuk Cengkih dalam Menekan Pertumbuhan Jamur Sclerotium rolfsii Penyebab Layu Skerotium pada Kedelai. Tesis. Universitas Gadjah Mada, Yogyakarta.

Cesniket, H.B., A. Gregorcic, S.V. Bolta, and V. Kmecl. 2006. Monitoring of pesticide residues in apples, lettuce and potato of the Slovene origin, 2001. Food Additives and Contaminants 23(2): 164-173.

Cibro, M.A. 2008. Respon Beberapa Varietas Kacang Tanah (Arachis hypogaea L). Terhadap Pemakaian Mikoriza Pada Berbagai Cara Pengolahan Tanah. Sekolah Pasca Sarjana, Universitas Sumatera Utara. Medan. 
Fichtner, E.J. 2010. Sclerotium rolfsii: Kudzu of the fungal world. North Carolina State University. https://projects.ncsu. edu/cals/course/pp728/Sclerotium/Srolfsii.html.

Giordani, R., Y. Hadef, and J. Kaloustian. 2008. Compositions and antifungal activities of essential oils of some Algerian aromatic plants. Fitoterapia 79: 199-203. DOI: 10.1016/j.fitote.2007.11.004.

Irfan, M. 2016. Uji pestisda nabati terhadap hama dan penyakit tanaman. Jurnal Agroteknologi 6(2): 39-40. DOI: 10.24014/ja.v6i2. 2239.

Lolong, A.A., Salim dan L.L. Barri. 2017. Serangan cendawan Sclerotium rolfsii pada beberapa varietas kedelai yang ditanam di beberapa sistem tanam kelapa. Buletin Palma 17(2): 139-146.

Novita, T. 2008. Peran daun cengkeh terhadap pengendalian layu Fusarium pada tanaman tomat. Jurnal Agronomi 12(2): 14-17.

Nurmansyah. 2016. Pengaruh minyak nabati Piper aduncum terhadap jamur Sclerotium rolfsii menurut ketinggian lokasi tanam dan waktu penyulingan. Buletin Penelitian Tanaman Rempah dan Obat 27(2): 147-154. DOI: http://dx.doi.org/10.21082/bullittro. v27n2.2016.147-154.

Punja, Z.K. 1985. The biology, ecology, and control of Sclerotium rolfsii. Annual Review of Phytopathology 23: 97-127. DOI: http://dx.doi.org/10.1146/annurev.py.23.090185.000525.

Semangun, H. 2004. Pengantar Ilmu Penyakit Tumbuhan. Yogyakarta: Gajah Mada University Press. ISBN: 979-420-383-1.

Sumartini. 2012. Penyakit tular tanah Sclerotium rolfsii dan Rhizoctonia solani pada tanaman kacang-kacangan dan umbi-umbian serta cara pengendaliannya. Jurnal Litbang Pertanian 31(1): 27-34. DOI: http://dx.doi.org/10.21082/ jp3.v31n1.2012.p\%25p.

Tawa, M.A., I.R. Sastrahidayat, dan S. Djauha. 2017. Efektivitas pestisida nabati untuk pengendalian jamur Sclerotium rolfsii Sacc. penyebab penyakit rebah semai pada tanaman kedelai. Jurnal HPT 5(2): 43-51.

Timper, P., N.A. Minton, A.W. Johnson, T.B. Brenneman, A.K. Culbrreat, G.W. Burton, S.H. Baker, and G.J. Gascho. 2001. Influence of cropping system on stem rot (Sclerotium rolfsii), Meloydogyne arenaria, and the nematode antagonist Pasteuria penetrans in peanut. Plant Disease 85: 767-772. DOI: 10.1094/PDIS.2001.85.7.767.

Ueda, S., B. Yamashita, M. Nakajima, and Y. Kuwahara. 1982. Inhibition of microorganisms by spice extracts and flavouring compounds. J. Japan. Soc. Food Sci. Technol. 29:111. 